\title{
CONTAINMENT OF SOYBEAN MEAL OF PLANT ESTROGEN DISRUPTS GONADS DEVELOPMENT OF NILE TILAPIA
}

\author{
M. A. Amer \\ Animal Production Department, Faculty of Agriculture, Ain Shams University, P.O. Box 68, Hadayek \\ Shobra 11241, Cairo, Egypt. \\ Corresponding author: amer_fish@yahoo.com
}

(Received 13/6/202 1, accepted 9/8/2021)

\section{SUMMARY}

\begin{abstract}
$\mathrm{T}$ The objective of this experiment was to study the effect of replacing fishmeal as a protein source in tilapia diets with different percentages of soybean meal on gonadal development and fish fertility. Four diets were tested in which fishmeal was partially replaced by four different soybean meal levels $(20,30,40$ and $50 \%)$ in tilapia diets. A histological examination was performed to monitor the development of the gonads. Results showed that the final body weight was significantly affected $(\mathrm{P}<0.05)$ by partial replacement of the fishmeal up to $50 \%$. Histological examination of the gonads showed deterioration in the development of the gonads increased by increasing the dietary percentage of soybean meal. Lower replacement rates (20 to 30\%) were less effective unless used for a long time, especially in males. When the replacement ratio was 40-50\%, the testicular deterioration was clearly observed by the degeneration of the germinal epithelial tissue and the somatic cells that regulating the testis function. Female gonad was also affected by both low and high replacement rates, which resulted in delayed sexual maturity and increased number of degraded eggs. These negative effects can be attributed to contain soybean meal high levels of plant estrogen. As a conclusion, substituting soybean meal instead of fishmeal as a source of protein up to $50 \%$ was significantly affect growth performance of tilapia fish. Moreover, increasing the replacement ratio to 40-50\%, significantly hampered the development of gonads and fertility of both sexes of tilapia due to the containment of soybean meal high levels of phytoestrogen. Therefore, it could be recommended to avoid using high levels plant protein in broadstock diets to maintain the fish fertility and fecundity.
\end{abstract}

Keywords: Nile tilapia, soybean meal, phytoestrogen, growth, gonads and histology.

\section{INTRODUCTION}

Fishmeal and fish oil are considered the most nutritious and most digestible ingredients for farmed fish feeds, but their inclusion rates in compound feeds for aquaculture have shown a clear downward trend as they are used more selectively (FAO, 2018). High quality fishmeal preferred as a major portion of protein in commercial fish feeds due to it is containing all the essential amino acids. However, fishmeal prices may represent limitations in the development of Egyptian aquaculture (Wassef, 2005). Soybean is the most regularly utilized plant protein source to supplant fishmeal in aquaculture diets (Martins et al., 2017). However, there has often been a decline in fish growth in soybean meal replacement diets (Floreto et al., 2000). Plant proteins are deficient in certain amino acids such as lysine, methionine, threonine, and tryptophan (Li et al., 2009).

Phytoestrogens are plant-derived substances which are to some extent like the estrogen either in structure or function (Cassidy et al., 2000; Jourdehi et al., 2013). Isoflavones, a group of phytoestrogens, and their derivatives such as coumestrol, formononetin, daidzein, biochanin A, genistein and equol can be found in several plants, especially in the legume family including soybean (Pelissero et al., 1991). ElSayed et al. (2012) considered the impact of genistein and daidzein, the major two significant metabolites of isoflavone, present in soybean on sex reversal of Nile tilapia larvae fed, these outcomes uncovered that phytoestrogen have estrogenic effects on Nile tilapia. The estrogenic action can be improved after metabolization to increasingly active compounds such as daidzein and genistein by the gut microorganisms (Zhengkang et al., 2007; Jourdehi et al., 2014). Isoflavones act as agonists of estrogen receptors, which may influence reproductive development and sex differentiation in fish (Pelissero et al., 1991; El-Sayed et al., 2012). Moreover, it has been suggested that phytoestrogen exposure may interfere 
with the pathway of androgen receptor and impact the late spermatogenesis steps (Giwercman, 2011).

The objective of this study was to investigate the effect of replacing fishmeal by different percentages of soybean meal on growth, gonads development and fertility of tilapia (Oreochromis niloticus).

\section{MATERIALS AND METHODS}

The experiment was carried out in a closed water system of Fish Production Branch, Department of Animal Production, Faculty of Agriculture, Ain Shams University. Twelve quadrate fiberglass tanks (60 $\times 60 \times 50 \mathrm{~cm}$ ) with a capacity of $180 \mathrm{~L}$ were used. Dechlorinate water in the experimental tanks was continuously aerated using air stones connected with $0.12 \mathrm{HP}$ air blower. The unclean water drained from the tanks was piped into mechanical and biological filtration system, then returned to the fish tanks. So, the recirculating system saves the environmental conditions nearly constant.

\section{Water quality:}

The water temperature and dissolved oxygen were measured daily by oxygen meter (Lutron model Do- 5509, Taiwan) and the $\mathrm{pH}$ values were recorded by digital $\mathrm{pH}$ meter (Hanna model PHEP, USA). Total ammonia concentration was measured by comparison apparatus using HACH kits (Hach Co., Loveland, Colorado, USA). The percentages of unionized ammonia (NH3) was calculated from multiplying the total ammonia value by the appropriate factor according to the following equation:

$$
\text { Ammonia concentration }(\mathrm{mg} / \mathrm{L} \text { as } \mathrm{NH} 3)=\mathrm{A} / 100 \times 1.2 \times \text { total ammonia. }
$$

Where $\mathrm{A}$ is a coefficient related to water $\mathrm{pH}$ and temperature.

\section{The experimental Fish:}

Mixed-sex fingerlings of Nile tilapia, Oreochromis niloticus, were purchased from a private fish hatchery in El- Abbassa, El-Sharqiyah, Egypt. Fish were acclimated in indoor tanks for 14 days before the beginning of the experiment. A total of 240 fish were distributed in 12 tanks at a density of 20 fish/ tank with three replicates. The average initial weight of fish per each tank was ranged from $2.2-2.4 \mathrm{~g} /$ fish indicating the randomization distribution of fish among the experimental fish groups. Fish were fed one of the formulated diets containing $30 \%$ crud protein and $343.1 \mathrm{kcal}$ (GE/ 100g diet) (D1, D2, D3 and D4) at a ratio of $3 \%$ of the fish total biomass divided into two times a day at 9 am and 4 pm (6 days a week). Fish in each tank were weighed every two weeks during the experimental period ( 24 weeks) to readjust the feeding regime.

\section{Histological examination:}

Every month, 6 fish from each treatment were dissected and their gonads (testes and ovaries) were cut into small pieces and fixed in formalin solution $10 \%$ for 24 hours. Gonads fragments were preserved in $70 \%$ ethanol, dehydrated through an ascending series of alcohol, embedded and blocked in paraffin wax. Fine transverse sections of $5 \mu$ were cut and stained with ordinary hematoxylin and eosin (H\&E) protocol according to Genten et al. (2009). The tissue slides were examined by light microscope and were photographed by a fluorescence Leica DM2500, Germany.

The examined sections were classified into several distinct spermatogenetic stages according to the most developed germ cell (Kosai et al., 2011) as follow: Stage I: immature testes were recognized by the absence of spermatogenetic activity in the germinative tissue compartment and the presence of primarily spermatogonia. No spermatozoa are present in the lobules. Stage II: early spermatogenesis was characterized by mostly thin germinative tissue compartment and the presence of primarily immature cells (spermatocytes to spermatids); however, some spermatozoa were also present. Stage III: midspermatogenesis, the germinative tissue compartment was moderately thick and some proliferation and maturation of the sperm could be observed; spermatocytes, spermatids and spermatozoa were present in roughly equal proportion. Stage IV: late spermatogenesis, the germinative tissue compartment was thick, although all cell types were represented, spermatozoa predominate in this stage. Stages from II to IV were characteristic of sexually mature fish, with the least activity occurring in stage II and the most activity taking place immediately prior to and during the spawning season (stage IV).

Female gonads were classified of being in one of six maturation stages according to a classification scale proposed by Srijunngam and Wattanasirmkit (2001) and Kosai et al. (2011); I- chromatin nucleus 
stage, II- perinucleolar stage, III- cortical alveoli formation stage, IV- vitellogenic (yolk) stage, V-ripe (mature) stage and VI- spent stage.

\section{Statistical analysis}

The data were subjected to analysis of variance (ANOVA) using one-way ANOVA. In all cases, significance was accepted at $\mathrm{P}<0.05$. Statistical analysis was performed using Statview 5.0 software for Windows (Abacus Concepts, Berkley, CA). All results are expressed as means \pm SE. Duncan's multiple range tests (1955) was used to compare between means.

\section{RESULTS AND DISCUSSION}

\section{Water quality:}

During the experimental period water quality parameters were within the accepted levels recommended for tilapia fish (El-Sayed, 2006), water temperature was maintained at $26 \pm 2{ }^{\circ} \mathrm{C}$; $\mathrm{pH}$ was $7.8 \pm 0.2$; dissolved oxygen (DO) was $5 \pm 0.5 \mathrm{mg} / \mathrm{L}$ and total ammonia was negligible.

\section{Body weight:}

Fish body weight was increased significantly $(\mathrm{P}<0.05)$ throughout the experimental period in the four treatments; the highest final body weight was obtained by a diet containing $40 \%$ soybean meal followed by a diet $4(50 \%)$ as shown in (Table 1). However, in the four treated diets the average final body weight was lower than expected which could be attributed to the culture of mixed tilapia. Moreover, body weight of fish fed diet 1 or 2 were lower than that of diet 3 or diet 4 , this could be also attributed to the sex ratio (female: male) in each tested diets, where these ratios were 78.6: 21.4 for T1, T2; 71.4: 28.6 for T3 and 57.1: 42.9 for T4. These results are consistent with the results of Furuya et al. (2004); Zhou and Yue (2010); Mahboob (2014) and Al-Thobaiti et al. (2018) which revealed that the replacement of fishmeal by plant protein sources improved fish performance to achieve better growth without any negative impact on fish, not only that but also reduced production costs, thereby increasing the net profit. In contrast, Yatawara and Hettiarachchi (2006) and Boussou et al. (2017) mentioned that there were no significant differences $(\mathrm{P}>0.05)$ in growth performance and feed utilization parameters of fish feed containing fishmeal or feed containing different replacing percentage by soybean meal (10-50\%) for GIFT tilapia, or diets containing $0 \%, 16.54 \%, 33.18 \%$ and $66.77 \%$ as the protein source for the African catfish, Clarias gariapinus (Ugwoke, 2013) and up to $30 \%$ without any reduction in growth rate of Egyptian sole (Bonaldo et al., 2006). Soltan et al. (2001) reported that after 16 weeks' experimental period, average body weights of Nile tilapia fish fed diets containing different percentages of soybean meal $(0 \%, 25 \%, 50 \%, 75 \%$ and $100 \%)$ were $58.80,52.83,51.90,47.42$ and $45.18 \mathrm{~g} /$ fish, respectively.

Table (2): Monthly body weight changes of $O$. niluticus fed diets containing different percentages of soybean meal instead of fishmeal.

\begin{tabular}{|c|c|c|c|c|}
\hline $\begin{array}{l}\text { Experimental Period } \\
\text { (month) }\end{array}$ & Diet $1(20 \%)$ & Diet $2(30 \%)$ & Diet $3(40 \%)$ & Diet $4(50 \%)$ \\
\hline $\begin{array}{l}\text { Initial } \\
1\end{array}$ & $\begin{array}{l}2.22 \pm 0.06 \\
5.31 \pm 0.30\end{array}$ & $\begin{array}{l}2.22 \pm 0.15 \\
5.53 \pm 0.38\end{array}$ & $\begin{array}{l}2.37 \pm 0.27 \\
5.12 \pm 0.24\end{array}$ & $\begin{array}{l}2.40 \pm 0.30 \\
5.69 \pm 0.59\end{array}$ \\
\hline & $11.92^{b} \pm 0.49$ & $12.84^{\mathrm{a}} \pm 01.14$ & $11.24^{b} \pm 0.60$ & $12.94^{\mathrm{a}} \pm 1.41$ \\
\hline 3 & $17.76^{b} \pm 1.0$ & $20.65^{\mathrm{a}} \pm 1.91$ & $20.44^{\mathrm{a}} \pm 0.64$ & $20.12^{\mathrm{a}} \pm 2.90$ \\
\hline 4 & $25.75^{\mathrm{c}} \pm 1.34$ & $28.83^{b} \pm 3.10$ & $30.61^{a} \pm 0.815$ & $27.52^{b} \pm 3.63$ \\
\hline 5 & $40.98^{\mathrm{d}} \pm 2.31$ & $43.14^{\mathrm{c}} \pm 5.00$ & $50.54^{\mathrm{a}} \pm 1.34$ & $45.46^{b} \pm 3.55$ \\
\hline 6 & $81.66^{\mathrm{d}} \pm 4.52$ & $95.00^{\mathrm{c}} \pm 11.67$ & $123.0^{\mathrm{a}} \pm 11.62$ & $114.33^{b} \pm 16.27$ \\
\hline
\end{tabular}

Values are the mean \pm S.E of triplicate groups.

Means in the same row having the same superscript letter were significant differences $(P<0.05)$.

It is clear that 50 to $100 \%$ replacement of FM by soybean meal can decrease the growth rate of Nile tilapia (Soltan et al., 2001; El-Marakby et al., 2012; Ajani et al., 2016; Sharda, et al. 2017), in rainbow trout (Hart et al., 2010), in red tilapia (Moharram and Raky, 2007), in sharp snout sea bream Diplodus 
puntazzo (Hernández et al., 2007), in African catfish Clarias gariepinus (Fagbemo and Davis, 2001; Toko, et al., 2008), and in juvenile cobia Rachycentron canadum (Chou, et al., 2004).

Essential amino acid deficiency has been widely demonstrated to reduce feed intake, where normal intake values are reached only when the amino acid concentration in the diet meets the requirements of the fish, as reviewed by De la Higuera (2001). Soybean meal is the vegetable-protein source most frequently used in practical diets to replace fish meal. Although, soybean protein has a well-balanced amino acid profile for fish, it is only low in methionine and lysine (Storebakken et al., 2000). Fish growth has almost always been retarded in direct relation to the level of replacement of fishmeal by soybean meal. This retardation could be attributed to the presence of residual levels of trypsin inhibitors, a less than optimal balance amino acid in soybean meal protein and deficiency in methionine is the first limiting in soybean meal protein. In addition to high levels of crud protein, soybeans contain approximately $30 \%$ carbohydrate, of which oligosaccharides make up $10 \%$ and non-starch polysaccharides make up the remaining $20 \%$ (Storebakken et al., 2000). These soy carbohydrates are not digestible by monogastric animals and some components show antinutritional effects in fish. Soybeans contain several antinutritional factors that are known to affect fish growth and health (Storebakken et al., 2000; Hendricks, 2002). Protease inhibitors inhibit trypsin and basic proteases in fish with considerable species variation. Most of the inhibitor activity is reduced in defatted soybean meal because of steaming in toasters during the oil extracting processes.

\section{Histological Observation:}

Male:

After two months of feeding the experimental diets, testicular sections from fish fed diets containing $20 \%$ and $30 \%$ soybean meal instead of fishmeal showed spermatogenetic activity where all germ cell types including spermatozoa existed in testicular lobular lumens (Figure 1, A and B). However testicular sections from fish fed diets containing $40 \%$ and 50\% soybean meal appeared completely undifferentiated or immature as recognized by the absence of spermatogenetic activity and the presence of cords of primarily spermatogonia separated by thick connective tissue bundles, no signs of spermatogenesis were observed (Figure 1, C and D).

Despite the presence of spermatogenetic activity in sections A and B, reduction in testicular tissue and some vacuoles (V) are existed between germinal epithelium compartments.

The soybean had inherent properties that had negative effects on the gonadal growth and development. Diet 1, (20\% soybean meal diet), came up as the best fish diet for overall gonad development among the four treatments. The $20 \%$ inclusion of soybean meal in diet had no effect on the gonad weight of the male catfish (Ugwoke, 2013).

Histological examination of testicular sections from fish fed different diets for four months showed variation in spermatogenetic process between different fish groups. Although all fish exhibited spermatogenetic activity, fish fed low percentage of soybean male (20\% and 30\%) were more active than the other two groups. Presences of spermatozoa was more pronounced in the first two groups (Figure 2, A and B). It is also noticed increase numbers of vacuoles within seminiferous tubules and hypertrophied Leydig cells. However, testes of fish fed diets have the higher percentages of soybean meal ( $40 \%$ and $50 \%$ ) were less developed with some deterioration in germinal epithelium compartments (Figure 2 C, D).

After feeding period of six months, deterioration of testicular tissue and degeneration of both germ and somatic cells were pronounced in all fish groups (Figure 3, A and D) especially fish fed higher percentage of soybean meal instead of fishmeal. Despite the presence of some spermatozoa almost other germ cell types are disappeared (Figure 3, C and D). 

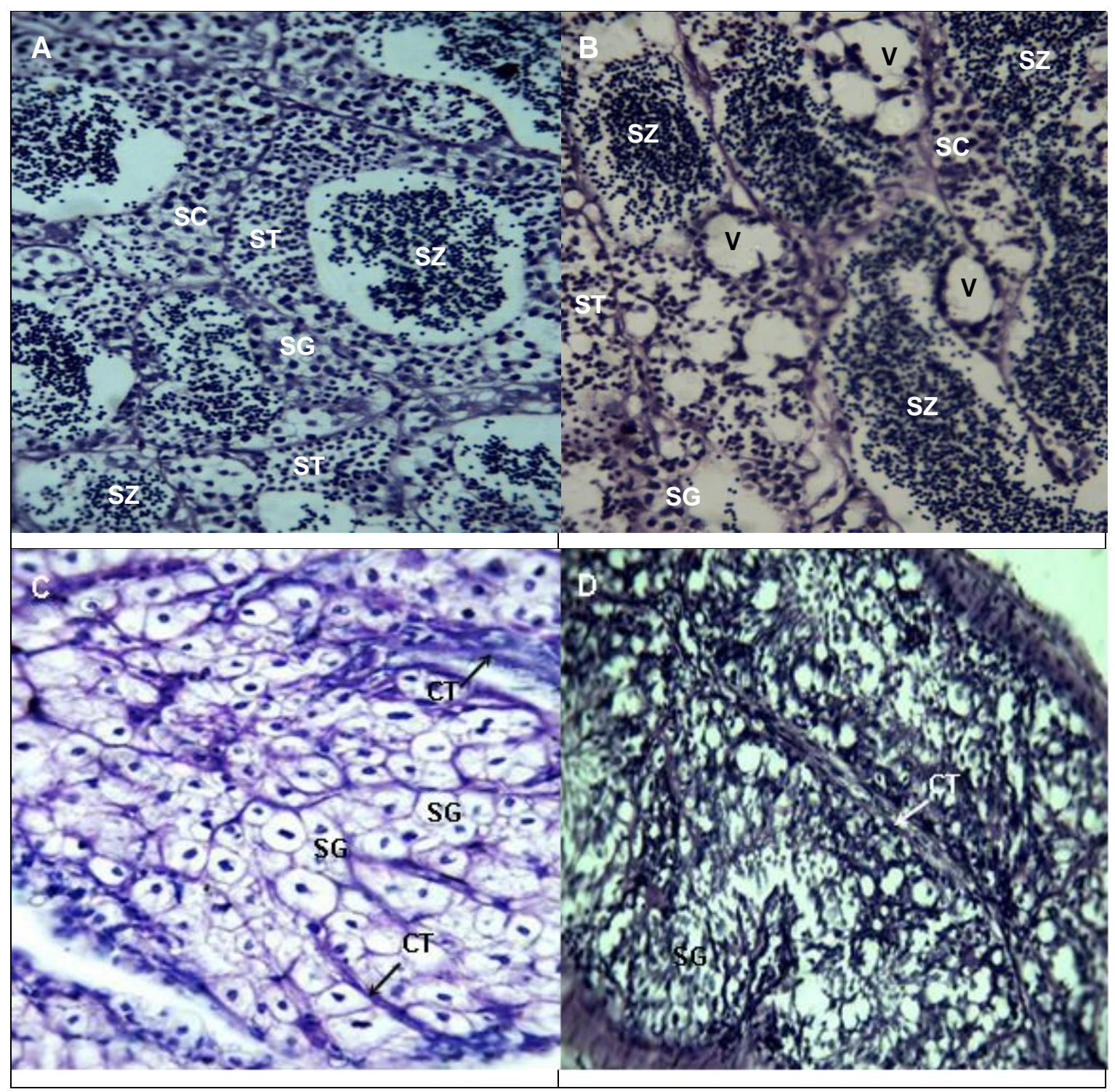

Figure (1): Testicular sections after two months of fish fed diets containing different percentages of soybean meal instead of fishmeal x20. Testicular sections A and B from fish fed diets containing $20 \%$ and $30 \%$ soybean meal showed spermatogenetic activity as recognized by the presence of all germ cell types including spermatogonia (SG), spermatocytes (SC), spermatids (ST) and spermatozoa (SZ) existed in testicular lobular lumens. However, C and D are testicular sections from fish fed diets containing $40 \%$ and $50 \%$ soybean which appeared completely immature or undifferentiated as recognized by the absence of spermatogenetic activity in the germinative epithelial tissue compartment and the presence of cords of primarily spermatogonia (SG) separated by connective tissue septum $(\mathrm{CT})$. 


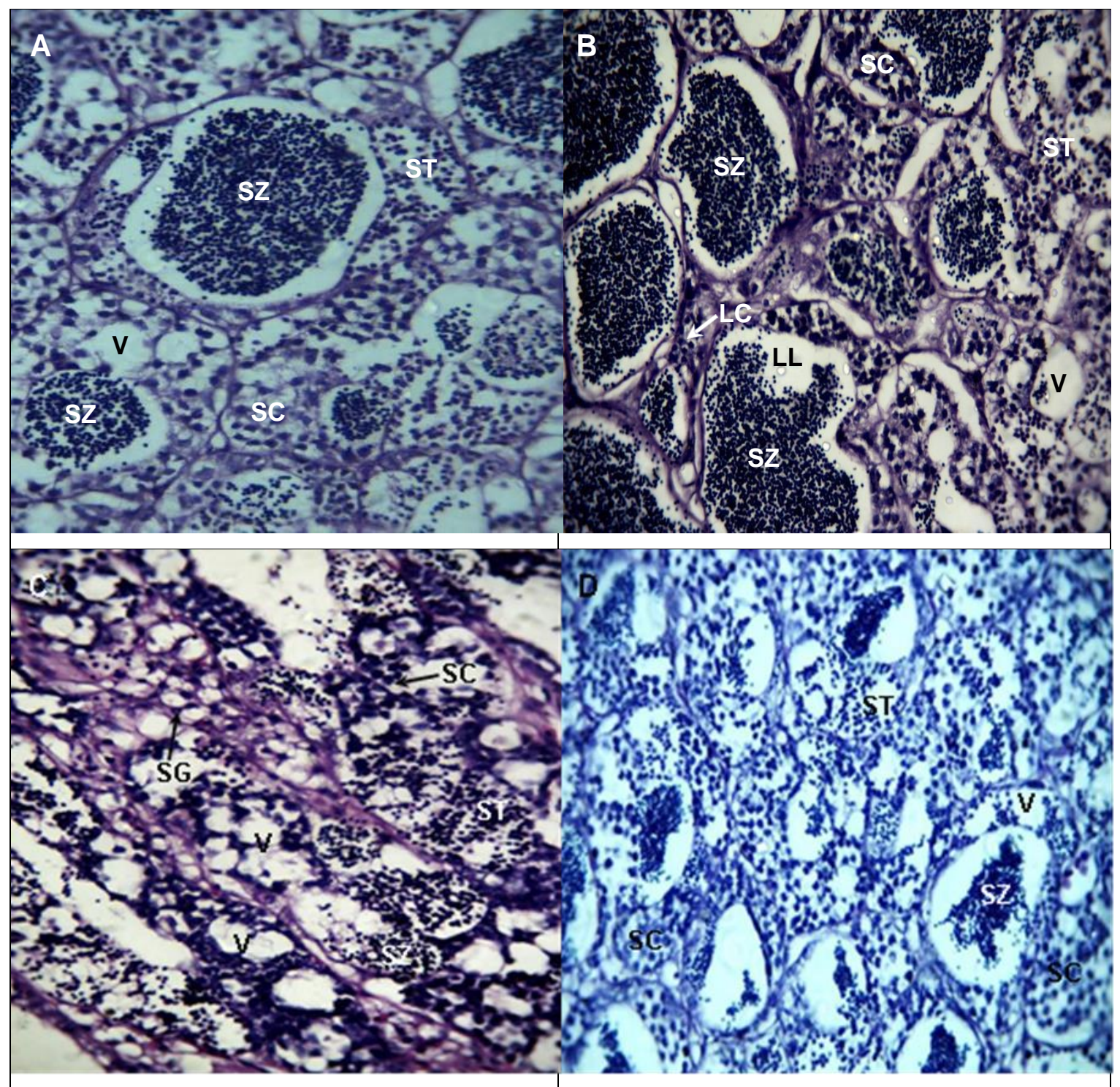

Figure (2): Testicular sections from fish fed diets containing different percentages of soybean meal instead of fishmeal for four months stained with H\&E x40. Testicular sections A and B from fish fed diets containing $20 \%$ and $30 \%$ soybean meal showed active spermatogenetic stage as recognized by the presence of all germ cell types including spermatozoa (SZ) existed in testicular lobular lumens (LL). However, C and D are testicular sections from fish fed diets containing $40 \%$ and $50 \%$ soybean showed some activity of spermatogenesis as indicated by the presence of a few cysts of spermatozoa. In the latter two fish groups retardation of germ cell development was observed with destruction in germinal epithelium, increasing vacuoles (V) within germinal compartment and the presence of empty spermatogenetic cysts. 

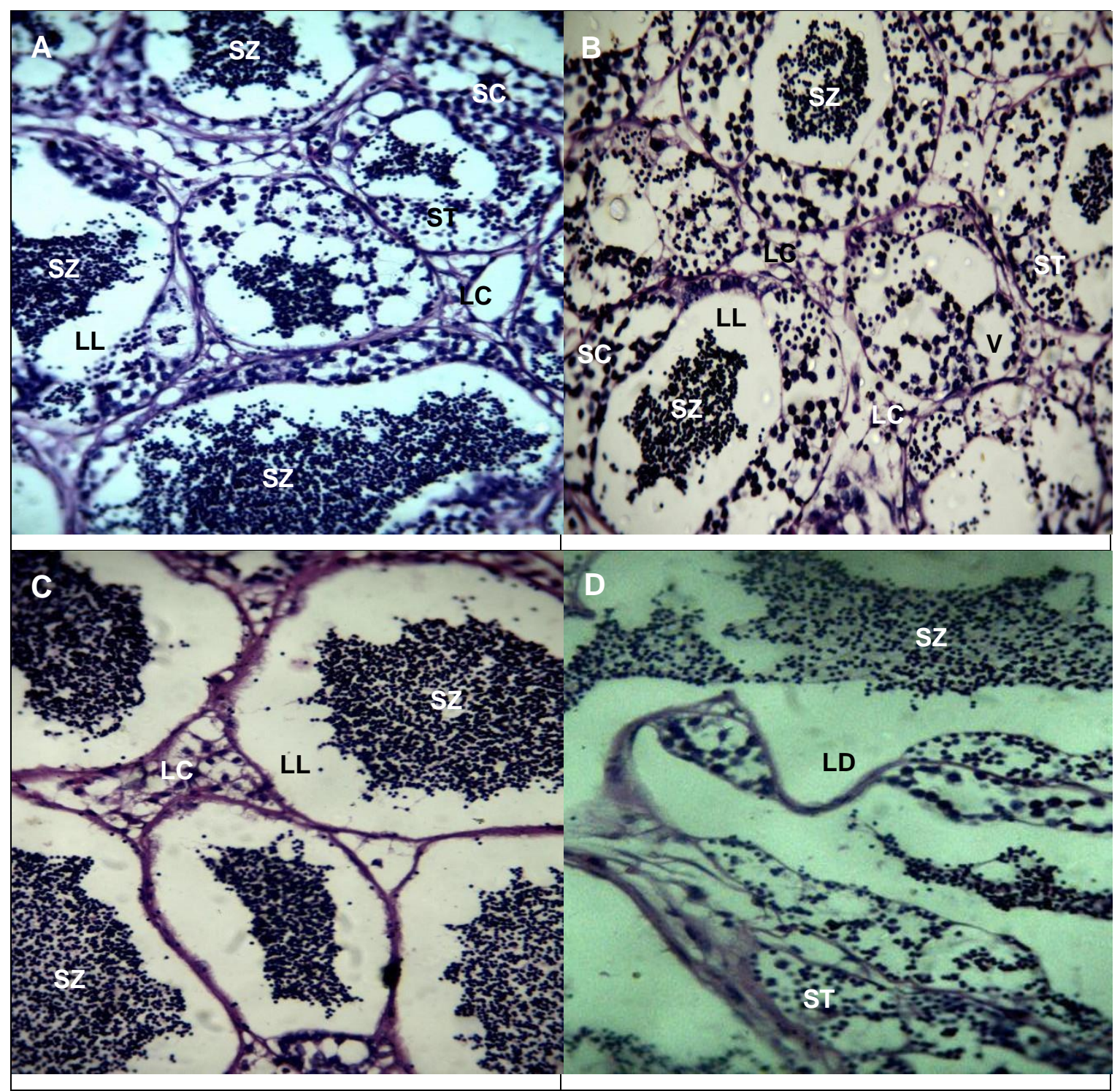

Figure (3): Testicular sections after six months from fish fed diets containing different percentage of soybean meal instead of fishmeal, x40. Testicular sections A and B from fish fed diets containing $20 \%$ and $30 \%$ soybean meal showed prominent reduction in both germinal epithelium and somatic compartment (degenerating of Leydig cells) as recognized by the thin wall of testicular lobule, abnormal architecture of testis parenchyma and the distribution of vacuoles (V) within testis lobules. Sections from fish fed high percentage (40\% and 50\%) of soybean meal (C and D) showed almost disappearance of germinal epithelium despite the presence of some lobules contained spermatozoa in testicular lobular lumens (LL) and ducts (LD). In the latter two fish groups retardation and destruction of germ cell and somatic cells was more pronounced and most testicular parenchyma was disappeared. Degeneration of Leydig cell (LC) was also noticed, spermatocytes (SC), spermatids (ST) and spermatozoa (SZ) existed in some testicular lobules.

\section{Female:}

Ovarian growth typically is divided into three phases, i.e., primary (previtellogenic) growth, oocyte growth (vitellogenesis) and oocyte maturation (Tyler and Sumpter, 1996). Female gonads were classified of being in one of six maturation stages according to a classification scale proposed by Srijunngam and Wattanasirmkit (2001); Heidari et al. (2009) and Kosai et al. (2011); I: chromatin nucleus stage, the oocyte is small in size, spherical in shape, has strong basophilic cytoplasm and centric nucleus contained one to three nucleoli together with chromatin network, the oocyte itself is entirely surrounded by a few squamous follicle cells; II: perinucleolar stage, characterized by several smaller nucleoli neatly arranged on the inner side of nuclear envelop and the nucleus (germinal vesicle) increased in size, these two stages referred as previtellogenic oocyte stage, or primary growth stage which is gonadotropin- independent 
stage; III: cortical alveoli formation stage, characterized by the appearance of clear vesicles (alveoli) appeared initially at the peripheral zone of the cytoplasm and gradually progressed towards the center of the oocyte, this is the first structures to appear within the oocyte cytoplasm during the gonadotropindependent growth phase; IV: vitellogenic (yolk) stage, characterized by extensive elaboration of cortical alveoli, appearance of yolk globules, with progress of vitellogenesis both the size and accumulation of yolk bodies increased remarkably and later incorporated the whole cytoplasmic area resulting in increased oocytes size, clearly visible a noncellular deep eosinophilic band (zona radiate), and follicular cell layers well developed with simple columnar inner granulosa cell layer surrounded by outer stratified squamous theca cell layer; V: ripe (mature) this phase includes two stages (early and final maturation), began with coalescence of yolk globules, completion of the germinal vesicle migration to the animal pole and completed by germinal vesicle breakdown (GVBD); and VI: spent stage, ovaries contained few large oocytes that probably belonged to the same batch of ova that had just been spawned which will be rapidly eliminated, large atretic follicles were presented. Atretic state characterized by liquefied cytoplasm, erosion of oocyte membrane which gave abnormal shape of oocyte, fibrosis, vacuoles and granulose cells attached to yolk matter that degenerated gradually until the oocyte disappear (Shalloof and Salama, 2008).

After two months of feeding various diets, histological examination of the female gonads showed that all females were in immature phase (Figure 4) as indicated by the pronounced proportion of small previtellogenic oocytes in earlier stages of development including chromatin nucleus stage and perinucleolar stage. Vitellogenic oocyte were also existed by the appearance of the cortical alveoli and vitellogenic oocyte stages. Previtellogenic were prominent in all ovarian section specially in the ovarian section of the fourth treated fish groups. Atretic oocytes were also observed in all ovarian sections. The ovary contains numerous of oocytes in different stages of development: perinucleolar, cortical alveoli stage and vitellogenic oocytes (growing oocytes). The yolk vesicles increased in number and fill the entire ooplasm resulting in increasing the size of oocytes, and germinal vesicle still in the center of the oocytes.
\end{abstract}




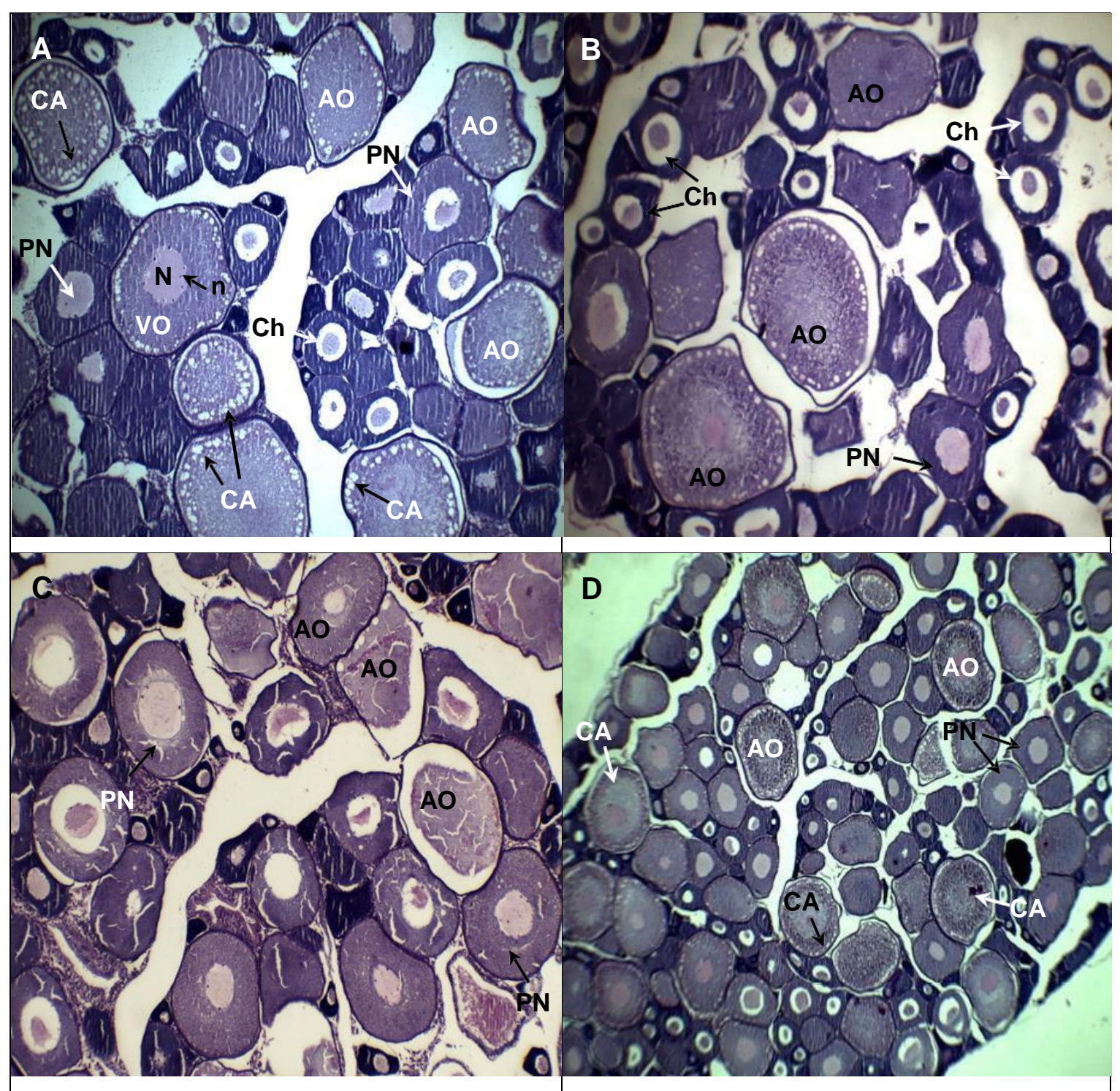

Figure (4): Transverse sections of female ovary of Nile tilapia after two months of feeding diets contained $20 \%$ (A), 30\% (B), 40\% (C) and 50\% (D) of soybean meal as a source of protein instead of fishmeal showing immature stage, $\mathrm{x} 20$. The ovary contains oocytes in differed stages of development either in previtellogenic stage involved chromatin nucleus stage $(\mathrm{Ch})$; perinucleolar stage $(\mathrm{PN})$; or in vitellogenic stage (growing oocytes) including cortical alveoli stage (CA) and vitellogenic oocytes (VO). $\mathrm{N}$ - nucleus (germinal vesicle) in the center of the oocytes and n-nucleoli arranged at the periphery of the nuclear envelop. Atretic oocytes (AO) were observed in all ovarian sections of treated groups. 

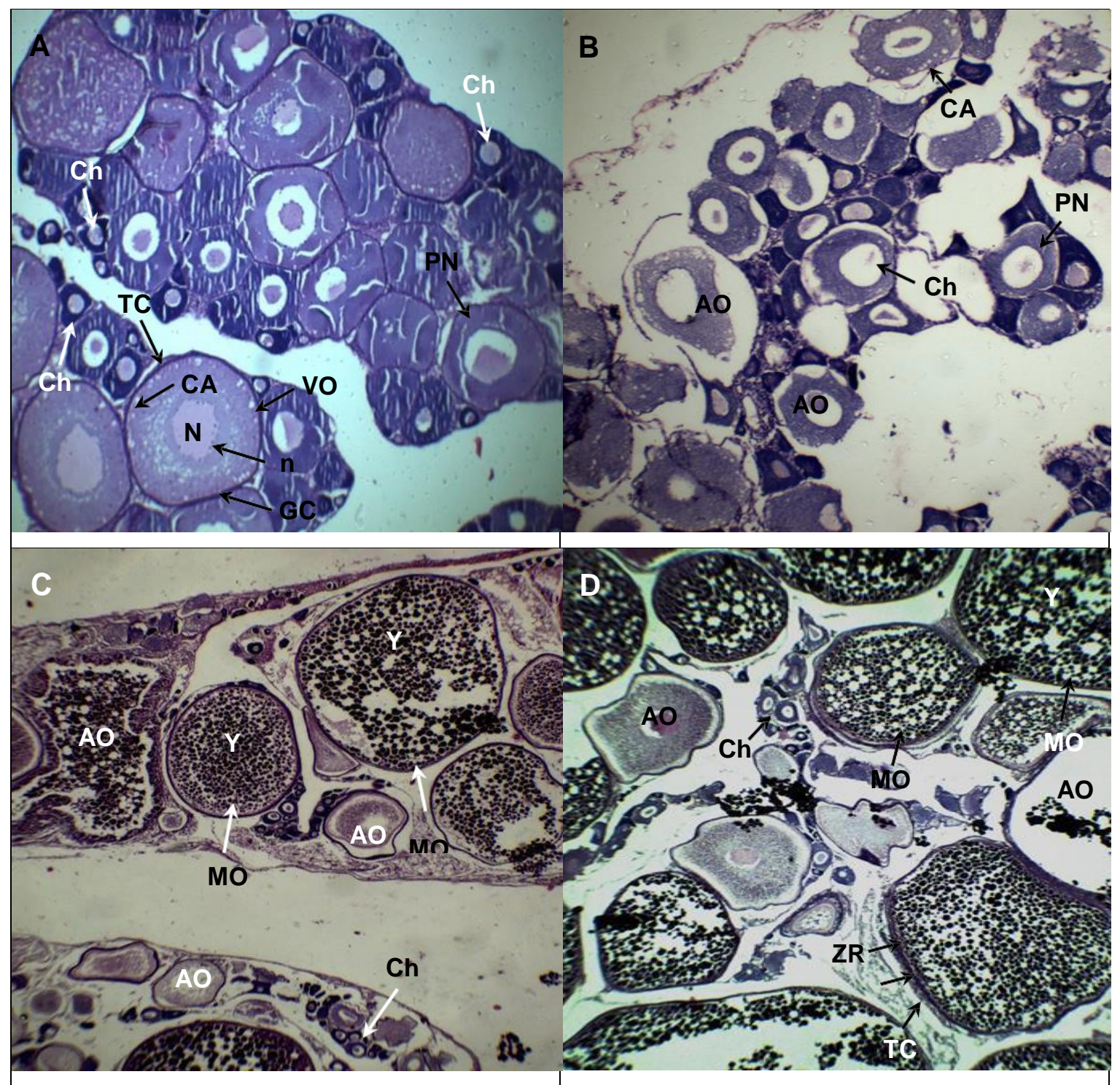

Figure (5): Transverse sections of female ovary of Nile tilapia after four months of feeding diets contained $20 \%, 30 \%, 40 \%$ and $50 \%$ of soybean meal as a source of protein instead of fishmeal showing different developing stages (A-D), x20. In section (A) the ovary contains oocytes in differed stages including perinucleolar stage (PN) cortical alveoli stage (CA) and a few vitellogenic oocytes (VO) containing vetillogenic vesicles occupied almost all oocyte cytoplasm and germinal vesicle $(\mathrm{N})$ with several nucleoli (n) still in the center of the oocyte. In section (B) most oocytes appeared in immature phase with normal perinucleolar oocytes and abnormal shape of vitellogenic or atretic oocytes. Mature oocytes appeared only in the ovarian sections taken from fish fed diets with higher percentage of soybean meal $(40 \%, \mathrm{C}$ and $50 \%, \mathrm{D})$ where vitellogenin or yolk fill almost all oocyte cytoplasm and the disappearance of germinal vesicle (nucleus). Zona radiate (ZR), inner granulosa cell layer (GC) and outer theca cell layer (TC) were clearly appeared surrounding the oocyte. Some atretic oocytes (AO) were also observed in all ovarian sections of treated groups. Simultaneous occurrence of oocytes in different Sizes within the ovaries is due to the fact that tilapia spawn more than once in the breeding cycle.

Microscopic examinations of ovarian sections prepared from fish fed diets contained different percentage of soybean meal instead of fishmeal for six months (Figure 6) showed that all fish were matured as confirmed by the presence of mature oocytes which were bigger, had rich lipid stores and disappearance of germinal vesicle (nucleus). Additionally, oocytes in the initial stage of developing "nests of oocytes at chromatin nucleus stage were distributed within the ovaries as the start point for a new patch. Occurrence of atretic oocytes were pronounced in ovarian sections of females fed diets containing lower percentage of soybean meal compared to other groups. 

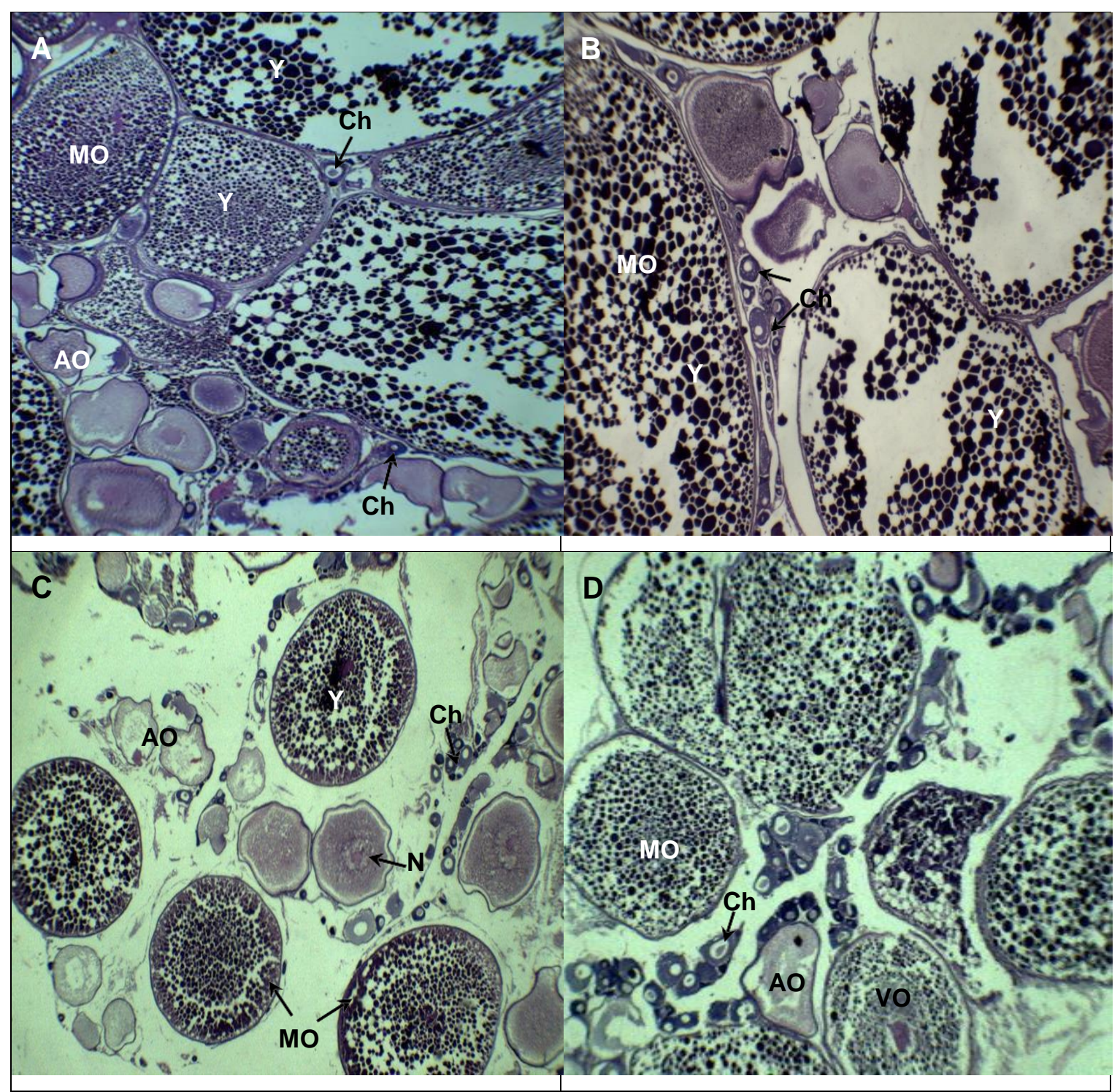

Figure (6): Transverse sections of ovary of female Nile tilapia fed diets contained different percentages of soybean meal instead of fishmeal for six months showing (A, B x40 and C, D x20) maturing stage, the ovary contains ripe (mature) oocytes filled by yolk globules (Y), vittelogenic oocytes (VO) contained centric nucleus $(\mathrm{N})$, atretic oocytes $(\mathrm{AO})$ and nests of chromatin nucleus stage $(\mathrm{Ch})$.

Histological examination of gonads revealed that males matured earlier than females, where after two months of feeding diets containing lower percentage $(20,30 \%)$ of soybean meal testicular sections exhibit spermatogenetic activity as confirmed by the presence of all spermatogenetic cell types including spermatozoa. Whereas mature oocytes appeared for the first time in the ovarian sections after four months of feeding diets contained higher percentages (40 and 50\%) of soybean meal. These findings agreed with those recorded by Moharram and Raky (2007) in red tilapia. Soltan et al. (2001) reported that in tilapia fed different diets contained $0 \%, 25 \%, 50 \%, 75 \%$ and $100 \%$ soybean meal showed normal appearance of the testis lobules, however, testis-ova were found in some testicular sections. The author also mentioned that no recognizable changes were observed in the male reproductive system of the control $(0 \%)$ and low $(25 \%)$ exposure groups throughout this experiment, where the testes had normal appearance, containing cells at all spermatogenetic stages, and classified as maturing testes.

Degeneration of testicular epithelial tissue, both spermatogenetic and somatic compartments were observed in males fed high percentages of soybean meal (Figures 1-3) which could be due to the higher containment of phytoestrogen, whoever this alteration occurred in fish fed lowered percentages of soybean meal only after a prolonged period of feeding the experimental diets.

Histological examination revealed that ovaries contained a mix of oocytes at varying stages of 


\begin{abstract}
Amer
development, after two months of feeding diets contained different percentages of soybean meal as a source of protein instead of fish meal, vitellogenic oocytes appeared firstly in fish fed lowered percentage, however in fish fed higher levels ovaries contained only oocytes at previtellogenic stage. Mature oocytes appeared after four months of the experimental period in females fed higher percentages of soybean meal. At the end of the experiment, all ovaries contained ripe oocytes in addition to nests of oocytes in chromatin nucleus stage. Atretic oocytes were also pronounced during the whole period of the experiment, which could be attributed to the interruption by phytoestrogen.
\end{abstract}

Soybean meal is the plant-protein source most frequently now a days used in practical diets to replace fish meal, but it contained isoflavonic phytoestrogens. These phyto-hormones "dietary estrogens" are diverse group of naturally occurring non-steroidal plant compounds that structurally or functionally mimic circulating estrogen. They have the ability to induce estrogenic and anti-estrogenic effects in the brain-pituitary-gonad axis and reproductive organs (Leusch et al., 2006; Zhao and Mu, 2011; Sicuro et al. 2010). Genistein and Daidzein are the major isoflavones compounds found in soy products. Their estrogenic activity can be enhanced by further metabolized to more active Equol by gut microorganisms (King and Bursill, 1998; Schoefer et al., 2002 and Zhengkang et al., 2007).

The present result showed that in Nile tilapia; diets containing high percentage of soybean meal cause slow rate of development of the gonads especially in fish fed high levels of soybean. Similar findings were also reported for Nile tilapia by Fontaínhas-Fernandes, et al. (2000) who showed that, diets containing only plant protein were less efficient in terms of growth and ovarian development. In addition, a study on catfish demonstrates that inclusion of soybean meal especially at high levels (above 35\%) in the diet had negative effects on the gonadal development and long term reproductive performance (Ugwoke, 2013). Poor gonadal growth due to plant protein source and also due to the effects of antinutritional factors in the soybean was reported for catfish fed diets contained $33.18 \%$ and $66.77 \%$ as the protein source compared to diets had $0 \%$ or $16.54 \%$ as indicated by the lower values of GSI. Higher levels of inclusion of soybean in the fish diet caused a reduction in oocyte number and development (Ugwoke, 2013).

Gonadal steroid is a very important factor in gonadal growth and development, exposure of male fish to phytoestrogens reduces the gonadal steroid biosynthetic capacity through effects on cholesterol availability in the male Maclatchy and Van Der Kraak (1995). Since sex steroid hormones are the regulators of gonadal development and maturation in all species (Dahle et al., 2003), low level of sex steroids leads to poor development thus contributing to the reproductive dysfunction in fish exposed.

Phytoestrogens have the ability to impair animal reproduction either by affecting gonad differentiation or by delaying maturation as illustrated by gradual degeneration of germinal epithelium of both gonads, which was pronounced in the germ cells, Sertoli cells and Leydig cells in males.

Phytoestrogens are able to stimulate vitellogenin synthesis by the liver and had a growth promoting similar to that of 17ß-estradiol in yellow perch (Ko et al., 1999) in Siberian sturgeon (Pelissero et al., 1991) and in vitro in trout hepatocyte (Pelissero et al., 1993). Reversely, Jourdehi, et al., (2013) reported that isoflavonic phytoestrogens can exhibit estrogenic activity on reproduction and exert ovary development at proper dosage and improve reproductive performance of female Huso huso may be mediated by their modulation of endocrine system. The author added that Equol exhibit more estrogenic effects on ovarian development compared to Genistein, suggesting use of Equol as a feed additive to induce ovarian development in farmed female $H$. huso. Phytoestrogen exposure may be less acute in mature female fish Betta splendens than in other fish (Brown, et al., 2014), The author reported only one effect of phytoestrogens on female behavior towards males and no effects were detected on gonado-somatic index or oocyte development.

As a conclusion, substituting soybean meal instead of fishmeal as a source of protein up to $50 \%$ was significantly affect growth performance of Nile tilapia. However, increasing the replacement ratio up to $40-50 \%$, significantly adverse the gonads development and fertility of both genders of tilapia due to the containment of soybean meal high levels of phytoestrogen. Therefore, it could be recommended avoiding using plant protein in broadstock diets to maintain fish fertility and fecundity.

\title{
REFERENCES
}

Ajani, E.K., Orisasona, O., Omitoyin, B.O. and Osho, E.F. (2016). Total Replacement of Fishmeal by Soybean Meal with or Without Methionine Fortification in the Diets of Nile Tilapia, Oreochromis 
niloticus. J. Fish. Aquat. Sci., 11(3): 238-243.

Al-Thobaiti, A., Al-Ghanim, K., Ahmed, Z., Suliman, E.M. and Mahboob, S. (2018). Impact of replacing fish meal by a mixture of different plant protein sources on the growth performance in Nile Tilapia (Oreochromis niloticus L.) diets. Braz. J. Biol., 78(3): 525- 534.

Bonaldo, A., Roem, A.J., Pecchini, A., Grilli, E. and Gatta, P.P. (2006). Influence of dietary soybean meal levels on growth, feed utilization and gut histology of Egyptian sole (Solea aegyptiaca) juveniles. Aquaculture, 261: 580-586.

Boussou, C.K., Aliko, G.N., Yoboué, N.A., Konan, F.K., Ouattara, M. and Gourène, G. (2017). Effect of Replacement of Fish Meal by Soybean Meal on Growth of Oreochromis niloticus (Linné, 1758) Juvenile under High Temperature Treatment for Masculinization. Int. J. Appl. Sci. Biotechnol., 5(1): 30-36.

Brown, A.C., Stevenson, L.M., Leonard, H.M., Nieves-Puigdoller, K. and Clotfelter, E.D. (2014). Phytoestrogens $\beta$-Sitosterol and Genistein have limited effects on reproductive endpoints in a female fish, Betta splendens. BioMed Research International, 7 pages.

Cassidy, A., Hanley, B. and Lamuela-Raventos, R.M. (2000). Isoflavones, lignans and stilbenes- origins, metabolism and potential importance to human health. J. Sci. Food Agric., 80: 1044-1062.

Chou, R.L., Her, B.Y., Su, M.S. Hwang, G., Wu, Y.H. and Chen, H.Y. (2004). Substituting fish meal with soybean meal in diets of juvenile cobia Rachycentron canadum. Aquaculture, 229: 325-333.

Dahle, R., Geir, L.T., Karlsen, Ø., Olav, S.K. and Norberga, B. (2003). Gonadal development and associated changes in liver size and sexual steroids during the reproductive cycle of captive male and female Atlantic cod (Gadus morhua L.) Comparative Biochemistry and Physiology Part A 136: 641653.

De la Higuera, M. (2001). Effects of nutritional factors and feed characteristics on feed intake. In: Houlihan, D., Boujard, T. and Malcolm, J. (eds.), Food Intake in Fish. Blackwell Science Ltd., pp. 250-268.

El-Marakby, H.I., Ayyat, M.S., Abd El-Rahman, M., Abd El-Rahman and Abd EL-Rahman, G.E. (2012). The effect of replacing fish-meal with soybean-meal on growth performance, feed utilization, blood parameters and body composition of Nile tilapia (Oreochromis niloticus). Zagazig Journal of Agricultural Research, 38(2): 443-464.

El-Sayed, A.M. (2006). Tilapia culture. CAB International, Wallingford, UK, pp. 293.

El-Sayed, A.M., Abdel-Aziz, E.H. and Abdel-Ghani, H.M. (2012). Effects of phytoestrogens on sex reversal of Nile tilapia (Oreochromis niloticus) larvae fed diets treated with $17 \alpha$ - Methyltestosterone. Aquaculture, 360-361: 58-63.

Fagbemo, O.A. and Davies, S.J. (2001). Use of soybean flour (deshelled, solvent-extracted soybean) as a fish meal substitute in practical diets for African catfish Clarias gariepinus (Burchell 1822): growth, feed utilization and digestibility. J. Appl. Ichthyol., 17: 64-69.

FAO (2018). The State of World Fisheries and Aquaculture 2018 - Meeting the sustainable development goals. Rome. License: CC BY-NC-SA 3.0 IGO., 227 pp.

Floreto, E. A. T.; R. C. Bayer and S. Brown (2000). The effects of soybean based diets, with and without amino acid supplementation, on growth and biochemical composition of juvenile American lobster, Hormarus americanus. Aquaculture, 189: 211-235.

Fontaínhas-Fernandes, M., Monteiro, M., Figueiredo, A., Gomes, E., Coimbra, J. and Reis- Henriques, M.A. (2000). Partial or total replacement of fish meal by plant protein affects gonadal development and plasma17 $\beta$-estradiol levels in female Nile tilapia. Aquaculture International, 8:299-313.

Furuya, W.M., Botaro, D., Neves, P.R., Silva, L.C.R. and Hayashi, C. (2004). Lysine requirement of Nile Tilapia (Oreochromis niloticus), for grow-out phase. Ciência Rural, Santa Maria, 34(5): 1571-1577.

Genten, F., Terwinghe, E. and Dangay, A. (2009): Atlas of Fish Histology. Science Publishers, Enfield, NH, USA. pp. 223.

Giwercman, A. (2011). Estrogens and phytoestrogens in male infertility. Current Opinion in Urology, 21(6): 519-526. 
Hart, S.D., Bharadwaj, A.S. Paul B. Brown, P.B. (2010). Soybean lectins and trypsin inhibitors, but not oligosaccharides or the interactions of factors, impact weight gain of rainbow trout (Oncorhynchus mykiss). Aquaculture 306 (2010) 310-314.

Heidari, B., Shabanipour, N., Savari, A., Yavari, V. and Hosseini, N. (2009). The oocyte development of Kutum, Rutilus frisii kutum, K. with special emphasis on the zona radiata structure. Anim. Reprod., 6(3): 465-472.

Hendricks, J.D. (2002). Adventitious toxins. In: Halver, J.E., Hardy, R.W. (Eds.), Fish Nutrition, $3^{\text {rd }}$ ed. Academic Press, San Diego, CA, USA, pp. 601- 649.

Hernández, M.D., Martínez, F.J., Jover, M., and García, G.B. (2007). Effects of partial replacement of fish meal by soybean meal in sharp snout seabream (Diplodus puntazzo) diet. Aquaculture, 263: 159167.

Jourdehi, A.Y., Sudagar, M., Bahmani, M., Hosseini, S. A., Dehghani, A.A., and Yazdani,M.A. (2014). Reproductive effects of dietary soy phytoestrogens, genistein and equol on farmed female beluga, Huso huso. Iranian Journal of Veterinary Research, 15(3): 266- 271.

Jourdehi, A.Y., Sudagar, M., Bahmani, M., Hosseini, S.A., Dehghani, A.A. and Yazdani, M.A. (2013). Comparative study of dietary soy phytoestrogens genistein and equol effects on growth parameters and ovarian development in farmed female beluga sturgeon, Huso huso. Fish Physiol. Biochem., 40(1): 117-128.

King, R.A., and Bursill, D.B. (1998). Plasma and urinary kinetics of the isoflavones daidzein and genistein after a single soy meal in humans. Am. J. Clin. Nutr., 67: 867-872.

Ko, K., Malison, J.A. and Reed, J.R. (1999). Effect of genistein on the growth and reproductive function of male and female yellow perch Perca flavescens. Journal of the World Aquaculture Society, 30: 73 78.

Kosai, P., Jiraungkoorskul, W., Sachamahithinant, C and Jiraungkoorskul, K. (2011) Induction of testisova in Nile tilapia (Oreochromis niloticus) exposed to 17ß-estradiol. Natural Science 3(3): 227-233.

Leusch, F.D., van den Heuvel, M.R., Chapman, H.F., Gooneratne, S.R., Eriksson, A.M. and Tremblay, L.A. (2006). Development of methods for extraction and in vitro quantification of estrogenic and androgenic activity of wastewater samples. Comp. Biochem. Physiol. (C): Toxicol. \& Pharmacol., 143(1): 117-126.

Li, K., Wang, Y., Zheng, Z.X., Jiang, R.L., and Xie, N.X. (2009). Replacing fish meal with rendered animal protein ingredients in diets for Malabar grouper, Epinephelus malabaricus, reared in net pens. J. World Aquacult. Soc., 40: 67-75.

Maclatchy, D.L. and Van Der Kraak, G.J. (1995). The Phytoestrogen, 6-Sitosterol Alters the Reproductive Endocrine Status of Goldfish. Toxicology and Applied Pharmacology, 134: 305-312.

Mahboob, S. (2014). Replacing Fish Meal with a Blend of Alternative Plant Proteins and its Effect on the Growth Performance of Catla catla and Hypophthalmichthys molitrix. Pakistan J. Zool., 46(3):747752.

Martins, G.P., Pezzato, L.E., Guimarães, I.G., Padovani, C.R., Mazini, B.C.M., Barros, M.M. (2017). Antinutritional Factors of Raw Soybean on Growth and Haematological Responses of Nile Tilapia. B. Inst. Pesca, São Paulo, 43(2): 322 - 333.

Moharram, S.G. and Raky, F.A. (2007). Effect of Varying Dietary Protein Sources on Growth and Spawning Performance and Gonad Maturation of Red Tilapia Reared in Sea Water. Pakistan Journal of Biological Sciences, 10(21): 3742-3751.

Pelissero, C., Flouriot, G., Foucher, J.L., Bennetau, B., Dunogues, J., Le Gac, F., Sumpter, J.P. (1993). Vitellogenin synthesis in cultured hepatocytes; an in vitro test for the estrogenic potency of chemicals. J. Steroid Biochem. Mol. Biol., 44: 263-272.

Pelissero, C., Le Menn, F. and Kausmckt, S. (1991). Estrogenic Effect of Dietary Soya Bean Meal on Vitellogenesis in Cultured Siberian Sturgeon Acipenser baeri. General and Comparative Endocrinology, 83: 447-457.

Schoefer, L., Mohan, R., Braune, A., Birringer, M., and Blaut, M. (2002). Anaerobic C-ring cleavage of genistein and daidzein by Eubacterium ramulus. FEMS Microbiol. Lett. 208, 197-202. 
Shalloof, K.A.S. and Salama H.M.M. (2008). Investigations on Some Aspects of Reproductive Biology in Oreochromis niloticus (Linnaeus, 1757) Inhabited Abu-zabal Lake, Egypt. Global Veterinaria, 2 (6): 351-359.

Sharda, Sharma, O.P. and Saini, V.P. (2017). Replacement of fishmeal with soybean meal in Nile tilapia (Oreochromis niloticus) Diet. Journal of Entomology and Zoology Studies, 5(4): 845-849.

Sicuro, B., Badino, P., Dapra, F., Gai, F., Galloni, M., Odore, R., Palmegiano, G.B. and Macchi, E (2010). Physiological effects of natural olive oil antioxidants utilization in rain bow trout (Oncorhynchus mykiss). Aquacult. Int., 18: 415-431.

Soltan, M.A., Ibrahim, M.K., Hafez, F.A. and Fath El-Bab, A.F. (2001). Effect of partial and total replacement of fishmeal by soybean meal on growth and proximate analysis of Nile tilapia. Egyptian J. Nutrition and Feeds, 4 (Special Issue): 799-812.

Srijunngam, J. and Wattanasirmkit, K. (2001). Histological structures of Nile Tilapia

Oreochromis niloticus Linn. Ovary. Nat. Hist. J. Chulalongkorn Univ., 1(1): 53-59.

Storebakken, T., Refstie, S. and Ruyter, B. (2000). Soy products as fat and protein sources in fish feeds for intensive aquaculture. In: Drackley, J.K. (ed.), Soy in Animal Nutrition. Federation of Animal Science Societies, Champaign, pp. 127-170.

Toko, I.I., Fiogbe, E.D. and Patrick Kestemont, P. (2008). Mineral status of African catfish (Clarias gariepinus) fed diets containing graded levels of soybean or cottonseed meals. Aquaculture, 275: $298-305$.

Tyler, C.R. and Sumpter, J.P. (1996). Oocyte growth and development in teleosts. Fish Biology and Fisheries, 6: 287-318.

Ugwoke, C.C. (2013). Effects of supplementation of fish meal with soybean meal on the growth and gonad development of the African catfish (clarias gariapinus). M. Sc. Thesis in Animal Science, Department of Animal Science, University of Nigeria Nsukka, pp. 79.

Wassef, E.A. (2005). Alternative protein sources for fish feeds in Egypt. Cahiers Options Mèditerranèennes, 63: 127-141.

Yatawara, M. and Hettiarachchi, M. (2006). Effect of dietary fishmeal replacement in the formulated food by heat processed soybean meal on growth, survival and crude protein level of fingerlings of Genetically Improved Farm Tilapia (GIFT). Sri Lanka J. Aquat. Sci., 11: 63-72.

Zhao, E. and Mu, Q. (2011). Phytoestrogen Biological Actions on Mammalian Reproductive System and Cancer Growth. Sci. Pharm., 79: 1-20.

Zhengkang, H., Wang, G., Yao, W. and Zhu, W. (2007). Isoflavonic phytoestrogens - new prebiotics for farm animals: a review on research in China. Curr. Issues Intestinal Microbiol., 7: 53-60.

Zhou, Q.C. and Yue, Y.R. (2010). Effect of replacing soybean meal with canola meal on growth, feed utilization and haematological indices of juvenile hybrid tilapia, Oreochromis niloticus $\times$ Oreochromis aureus. Aquaculture Research, 41: 982-990. 
احتواء كسب فول الصويا من هرمون الإستروجين النباتي يعطل تطور الغدد التناسلية للبلطي النيلى

محمة عبد الباقى عامر

قسم الإنتاج الحيوانى ـ كلية النزراعة ـ جامعة عين شمس - مصر.

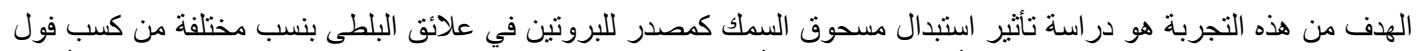

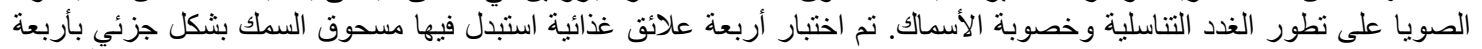

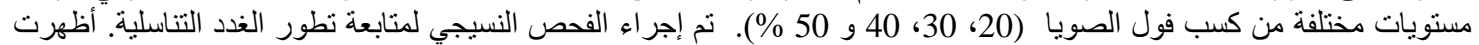

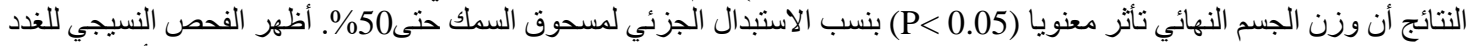

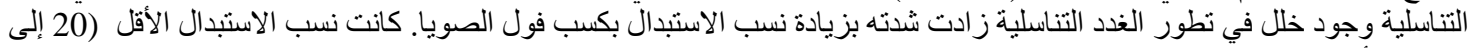

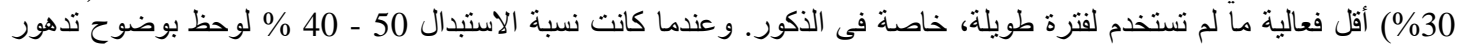

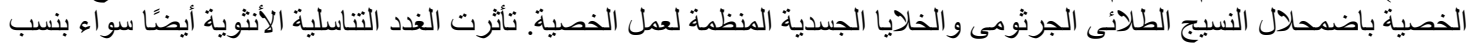

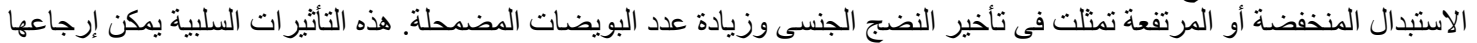

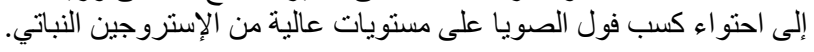

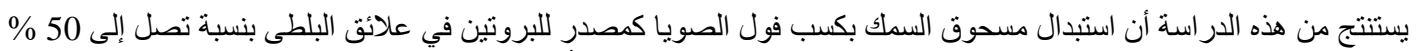

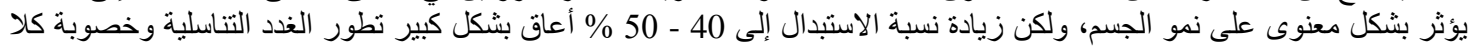

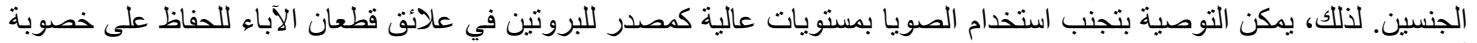
أسماك البلطى. 